\title{
Age-dependent changes in TDP-43 levels in a mouse model of Alzheimer disease are linked to $A \beta$ oligomers accumulation
}

\author{
Antonella Caccamo, Andrea Magrí, Salvatore Oddo*
}

\begin{abstract}
Background: Transactive response DNA-binding protein 43 (TDP-43) is the pathological protein found in frontotemporal lobar degeneration with ubiquitin positive inclusions and in amyotrophic lateral sclerosis. In diseased tissue, TDP-43 translocates from its physiological nuclear location into the cytoplasm, where it accumulates. Additionally, C-terminal fragments of TDP-43 accumulate in affected brain regions and are sufficient to cause TDP-43 mislocalization and cytoplasmic accumulation in vitro. TDP-43 also accumulates in 30\% of Alzheimer disease (AD) cases, a finding that has been highly reproducible. The role of TDP-43 in AD and its relation with $A \beta$ and tau pathology, the two neuropathological hallmarks of $A D$, remains to be elucidated.

Results: Here we show that levels of TDP-43 and its $\sim 35 \mathrm{kDa}$ C-terminal fragment are significantly increased in the $3 \times T g-A D$ mice, an animal model of AD that develops an age-dependent cognitive decline linked to the accumulation of $A \beta$ and tau. We also report that the levels of TDP-43 and its C-terminal fragment correlate with the levels of soluble $A \beta$ oligomers, which play a key role in $A D$ pathogenesis. Notably, genetically reducing $A \beta_{42}$ production restores the levels of TDP-43 and its $\sim 35 \mathrm{kDa}$ C-terminal fragment to control levels.

Conclusions: These data suggest a possible relation between A $\beta$ oligomers and TDP-43.
\end{abstract}

\section{Background}

Alzheimer disease (AD) is the most common cause of dementia among the elderly [1]. Clinical symptoms include memory loss and impairments in other domains that interfere with mood, reason, judgment, and language [2-4]. Two hallmark neuropathological lesions of $\mathrm{AD}$ include the aberrant accumulation of the amyloid- $\beta$ peptide $(\mathrm{A} \beta)$ and neurofibrillary tangles (NFTs) [5]. Other prominent changes include intraneuronal $A \beta$ accumulation, mitochondrial dysfunction, oxidative damage, and changes in the protein quality system [6-9]. $A \beta$ is the primary protein component of amyloid plaques and originates via proteolysis from the amyloid precursor protein $[10,11]$. $A \beta$ has been the central focal point of $A D$ research for more than a decade and is generally considered the upstream causative factor for $\mathrm{AD}$ [12]. The strongest evidence for this position is

\footnotetext{
* Correspondence: oddo@uthscsa.edu

Department of Physiology and The Barshop Institute for Longevity and Aging Studies, University of Texas Health Science Center at San Antonio, 7703 Floyd Curl Drive, San Antonio, TX 78229-3900, USA
}

derived from molecular genetic studies of the three genes (amyloid precursor protein, presenilin 1, and presenilin 2) that underlie familial AD cases, as they all modulate some aspect of $A \beta$ metabolism, increasing the propensity of $A \beta$ to aggregate [13-16]. Indeed, $A \beta$ is an aggregation-prone peptide, and it exists in different forms such as monomers, oligomers, and fibrils $[17,18]$. In the past few years, in vitro and in vivo studies have shown soluble $A \beta$ oligomers to be the major neurotoxic species for neurons [19].

The major component of NFTs is the microtubuleassociated protein, tau [20-23]. In its normal state, tau is a soluble protein whose function is to promote microtubule assembly and stabilization. Pathological tau protein, by contrast, exhibits altered solubility properties, forms filamentous structures, and is abnormally phosphorylated at specific residues [20-23]. Recent evidence indicates that the accumulation of soluble, phosphorylated tau may be more toxic than NFTs [24-27].

Transactive response DNA-binding protein 43 (TDP43 ) is a nuclear protein involved in exon skipping and 
alternative splicing [28]. The full length fragment has an approximate molecular weight of $\sim 44 \mathrm{kDa}$. Recently, TDP- 43 has been found to be the main protein that accumulates in frontotemporal lobar degeneration with ubiquitin positive inclusions (FTLD-U) and in amyotrophic lateral sclerosis (ALS) [29]. Pathological TDP-43 is mislocalized from the nucleus to the cytoplasm where it accumulates [29]. Additionally, TDP-43 C-terminal fragments have been isolated from affected brain regions $[29,30]$, and their expression in vitro is sufficient to cause TDP-43 mislocalization [31-33], suggesting that these fragments may play a role in the disease pathogenesis.

In addition to ALS and FTLD-U, TDP-43 positive inclusions are present in Parkinson disease, dementia with Lewy bodies, and in 30\% of AD cases [34-37]. The specific role of TDP-43 in AD has not been identified yet; specifically, it is not clear whether there is a link between TDP-43, A $\beta$ and tau pathology. In this study, we address the relation between $A \beta$, tau and TDP-43 in the $3 \times \mathrm{Tg}$ - $\mathrm{AD}$ mice, an animal model of $\mathrm{AD}$ that develops $\mathrm{A} \beta$ and tau pathology, with a temporal- and regional-specific profile that closely mimics their development in the human AD brain [38].

\section{Results}

The accumulation of TDP-43 has been linked to FTLD$\mathrm{U}$ and ALS [29]. TDP-43 also accumulates in Parkinson's disease, dementia with Lewy bodies, and in $30 \%$ of AD cases [34-37,39]. In AD brains, TDP-43 seems to prevalently accumulate in the brain areas more susceptible to $A \beta$ and tau pathology such as hippocampus, amygdala, and in selected cortical regions [40]. However, the relation between TDP-43, $\mathrm{A} \beta$ and tau is not known. To investigate the link between A $\beta$, tau and TDP-43, we first measured the steady-state levels of TDP-43 and its C-terminal fragments in the low salt fraction (see material and methods) of proteins extracted from in 2-, 6-, and 12-month-old $3 \times \mathrm{Tg}$-AD and NonTg mice $(\mathrm{n}=6 /$ genotype/time-point). We found that in the brains of 2month-old mice, the steady-state levels of TDP-43 and the $\sim 35 \mathrm{kDa}$ C-terminal fragment (herein referred to as TDP-35), which can be detected by overexposing the blots, were similar between $3 \times \mathrm{Tg}-\mathrm{AD}$ and age- and gender-matched non transgenic (NonTg) mice (Figure 1A$B)$. In contrast, the brains of 6 -month-old $3 \times \mathrm{Tg}$ - $\mathrm{AD}$ mice had significantly higher levels of TDP-43 and TDP-35 than the age- and gender-matched NonTg mice (Figure 1C-D). TDP-43 and TDP-35 levels were again similar between $3 \times \mathrm{Tg}-\mathrm{AD}$ and NonTg mice at 12 months of age (Figure 1E-F). The higher levels of TDP43 and TDP-35 in 6-month-old $3 \times$ Tg-AD mice coincided with the onset of $A \beta$ and tau pathology [38,41]. The difference in TDP-43 levels between $3 \times \mathrm{Tg}-\mathrm{AD}$ and
NonTg mice at 6 months of age might be due to a decrease in TDP-43 levels in the brains of 6-month-old $3 \times \mathrm{Tg}$-AD mice or to an increase in TDP-43 levels in 6 -month-old NonTg mice. To discriminate between these two possibilities, protein extracted from 2-, 6-, and 12-month-old NonTg mice were run on the same blot. We found that in NonTg mice, the levels of TDP-43 and TDP-35 were similar across the three different time points (Figure $2 \mathrm{~A}-\mathrm{B}$ ). In contrast, our results indicated that in the $3 \times \mathrm{Tg}-\mathrm{AD}$ mice the levels of TDP- 43 and TDP-35 were significantly higher at 6 months of age, compared to 2 and 12 months of age (Figure 2C-D). Taken together, these data indicate that the higher levels of TDP-43 and TDP-35 in the brains of 6-month-old $3 \times \mathrm{Tg}$-AD mice compared to NonTg mice are due to an increase of these proteins in the $3 \times \mathrm{Tg}-\mathrm{AD}$ mice as a function of age and not to a decrease of the levels of TDP-43 and TDP-35 in the brains of NonTg mice.

A neuropathological feature of TDP-43 proteinopathies is the mislocalization of TDP-43, from its predominantly nuclear location into the cytosol, where it accumulates [29] To determine whether there is mislocalization of TDP-43 and TDP-35 in the brains of the $3 \times \mathrm{Tg}-\mathrm{AD}$ mice, we extracted nuclear and cytosolic proteins from the brains of 2-, 6-, 12-month-old $3 \times \mathrm{Tg}-\mathrm{AD}$ and NonTg mice ( $n=6 /$ genotype/time-point). Using Western blot analysis, we found that at 2 and 12 months of age, the levels of TDP-43 and TDP-35 were not statistically different between $3 \times \mathrm{Tg}-\mathrm{AD}$ and NonTg mice in the nuclear and cytosolic fractions (Figure 3AC, G-I). In contrast, at 6 months of age, the levels of cytosolic TDP-43 and TDP-35 were significantly higher in the $3 \times \mathrm{Tg}-\mathrm{AD}$ mice compared to age- and gendermatched NonTg mice (Figure 3D-F). Unexpectedly, we found that the nuclear levels of TDP-43 and TDP-35 were not statistically different between NonTg and $3 \times \mathrm{Tg}-\mathrm{AD}$ mice (Figure $3 \mathrm{D}-\mathrm{F}$ ), suggesting that the increase of the levels in the cytosolic fraction is not simply due to a redistribution of TDP-43 from the nucleus into the cytoplasm. As expected, the levels of TDP-43 and its $\mathrm{C}$-terminal fragments were constantly higher in the nuclear fraction compared to the cytosolic fraction (Figure 3A, D, G). Moreover, in the cytosolic fraction, at all ages and independent of the genotype, the predominant species was TDP-35. In the nuclear fraction there were bands with different molecular weights, indicating more TDP-43 species. Future studies are needed to understand the nature of these fragments.

Tau pathology is another hallmark feature of $\mathrm{AD}$ and develops in the $3 \times \mathrm{Tg}$ - AD mice as a function of age $[38,42]$. In the $3 \times \mathrm{Tg}-\mathrm{AD}$ mice tau first accumulates in the somatodendritic compartment, and as the mice age, it becomes hyperphosphorylated and eventually aggregates to form NFTs [38,42]. Phosphorylation at Thr181 


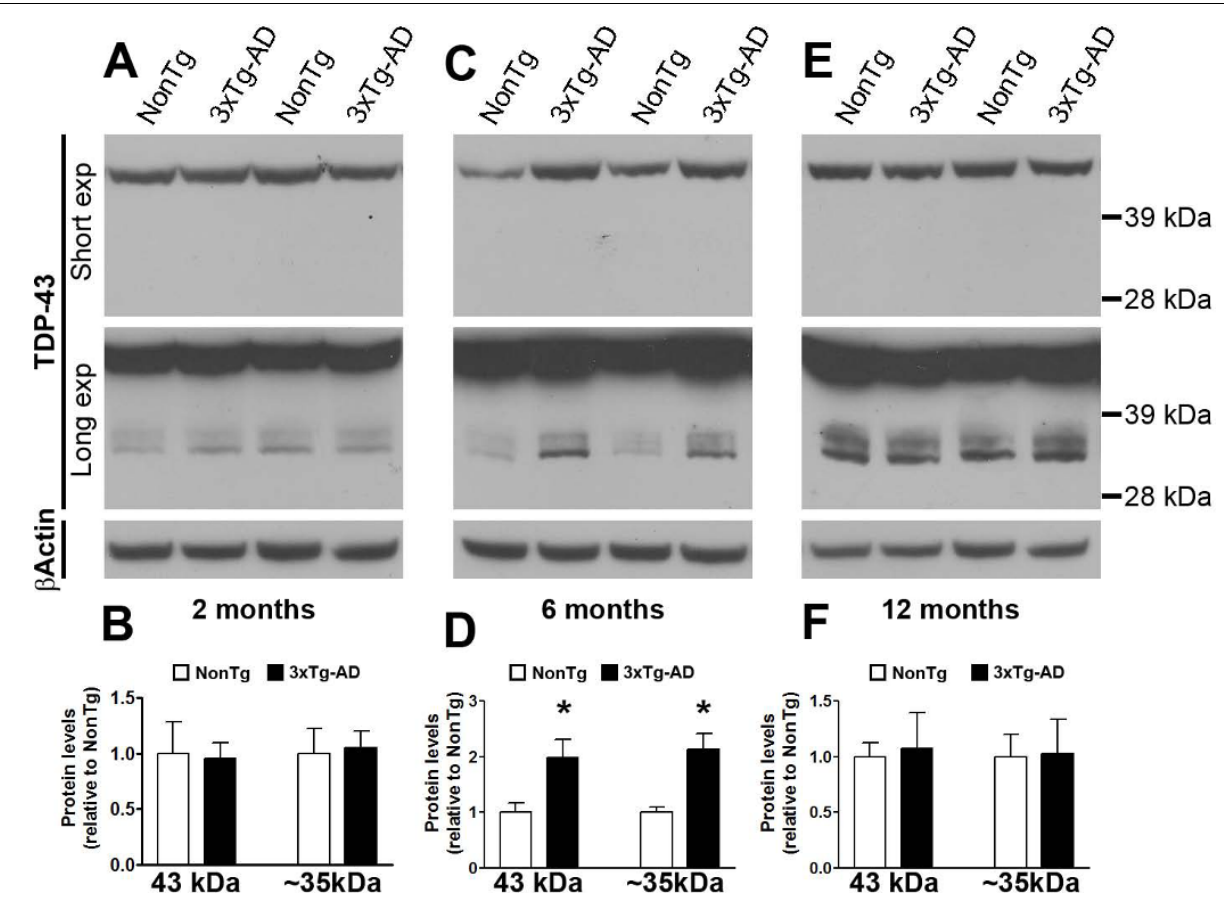

Figure $13 \times \mathrm{Tg}-\mathrm{AD}$ mice have higher levels of TDP-43 and TDP-35. (A) Representative Western blots of proteins from the low salt fraction extracted from 2-month-old 3xTg-AD and NonTg mice and probed with the indicated antibodies. A longer exposure time was necessary to see the less abundant low molecular weight fragments. (B) Quantitative analysis of the blots shows that at 2 months of age the levels of TDP-43 and TDP-35 were similar between 3xTg-AD and NonTg mice $(n=6 / g e n o t y p e)$. (C) Representative Western blots of proteins from the low salt fraction extracted from 6-month-old 3XTg-AD and NonTg mice. (D) Quantitative analysis of the blots shows that at 6 months of age the levels of TDP-43 and TDP-35 were significantly increased ( $p=0.04$ and $p=0.01$, respectively) in the brains of the $3 \times \operatorname{Tg}$-AD mice compared to ageand gender-matched NonTg mice ( $n=6 /$ genotype). (E) Representative Western blots of proteins from the low salt fraction extracted from $12-$ month-old 3XTg-AD and NonTg mice ( $n=6 /$ genotype). (F) Quantitative analysis of the blots shows that at 12 months of age the levels of TDP43 and TDP-35 were similar between $3 \times \operatorname{Tg}-\mathrm{AD}$ and NonTg mice $(n=6 /$ genotype). Abbreviation: exp $=$ exposure. Data are presented as \pm SEM and analyzed by t-test analysis.

(recognized by the anti-tau antibody, AT270) is one of the earliest manifestations of tau pathology in the $3 \times \mathrm{Tg}$ $\mathrm{AD}$ mice and occurs at 6 months of age (Figure 4A). As the mice age, AT270 immunoreactivity increases (Figure $4 \mathrm{~A})$, and the age-dependent increase is also detected by Western blot (Figure 4B-C). We next sought to determine whether there is a relation between AT270, TDP43 and TDP-35. We focused on the AT270 epitope because in the $3 \times \mathrm{Tg}$ - AD mice tau phosphorylation at Thr181 correlates with cognitive performance (e.g., [43]). Linear regression analysis indicated that the levels of AT270 in the brains of 6 -month-old $3 \times \mathrm{Tg}$-AD mice do not correlate with the levels of TDP-43 and TDP-35 (Figure 4D-E; $\mathrm{r}^{2}=0.09148, \mathrm{p}=0.56$; and $\mathrm{r}^{2}=0.1491$, $\mathrm{p}=0.45$, respectively). Neither was a correlation between AT270 and TDP-43 and TDP-35 levels observed at 12 months of age (Figure $4 \mathrm{~F}-\mathrm{G} ; \mathrm{r}^{2}=0.4644$, $\mathrm{p}=0.14$; and $\left.\mathrm{r}^{2}=0.4469, \mathrm{p}=0.15\right)$. The lack of correlation between TDP- 43 and tau is consistent with data showing that TDP-43 deposits in AD brains do not colocalize with NFTs or dystrophic neuritis [37].
Evidence indicates a primary role for $A \beta$ oligomers in $\mathrm{AD}$ pathogenesis [12]. In the $3 \times \mathrm{Tg}$ - $\mathrm{AD}$ mice, $\mathrm{A} \beta$ oligomerization starts intraneuronally, and a strong immunoreactivity can be detected with the M71/3 antibody, which is specific for low molecular weight $A \beta$ oligomers (Figure 5A, C; $[44,45]$ ). As the mice age, however, the intraneuronal M71/3 immunoreactivity decreases (Figure 5A-D). We have previously shown that this decrease in M17/3 in 12-month-old $3 \times \mathrm{Tg}$ - AD mice correlates with the appearance of extracellular $A \beta$ plaques [44]. Next, to further analyze the changes in $A \beta$ oligomer levels in the brains of the $3 \times \mathrm{Tg}$ - $\mathrm{AD}$ mice, we performed dot blot experiments using A11, an oligomeric-specific antibody that recognizes high molecular weight $A \beta$ oligomers [46]. Consistent with the M71/3 data, we found that the A11 levels peak at 6 months of age and decrease at 12 months of age (Figure 5E-F). To determine the relation between TDP-43, TDP-35 and A $\beta$ oligomers, we correlated oligomeric $A \beta$ levels obtained by A11 dot blot with TDP-43 and TDP-35 levels in 6- and 12 -month-old $3 \times \mathrm{Tg}$-AD mice. We found that in 


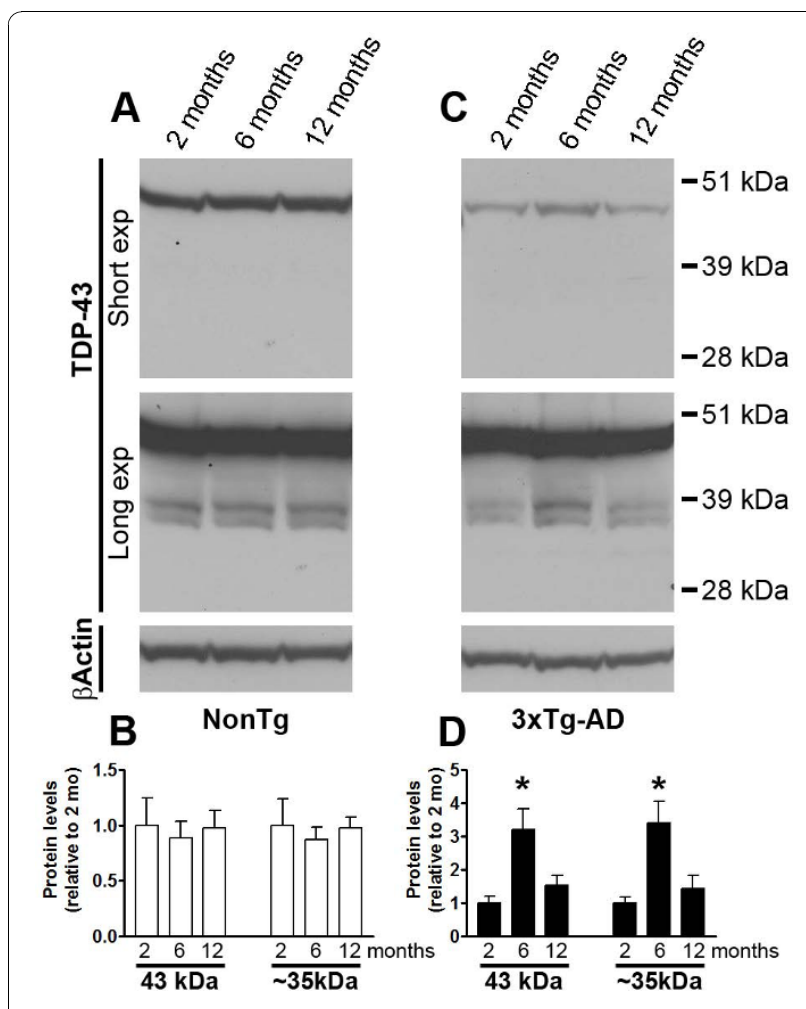

Figure 2 Age-dependent changes in TDP-43 and TDP-35 levels. (A) Representative Western blots of proteins from the low salt fraction extracted from 2-, 6- and 12-month-old NonTg mice and probed with a polyclonal antibody raised against TDP-43 antibody. A longer exposure time was necessary to see the less abundant low molecular weight fragments. (B) Quantitative analysis of the blots shows that the levels of TDP-43 and TDP-35 were similar across the three different ages analyzed ( $n=6 /$ time-point). (C) Representative Western blots of proteins from the low salt fraction extracted from 2-, 6- and 12-month-old 3XTg-AD mice and probed with a polyclonal antibody raised against TDP-43 antibody. (B) Quantitative analysis of the blots shows that the levels of TDP-43 and TDP-35 were significantly higher at 6 months of age ( $n=6 /$ time-point). Abbreviation: $\exp =$ exposure. Data are presented as \pm SEM and analyzed by one way ANOVA.

6-month-old $3 \times \mathrm{Tg}$ - $\mathrm{AD}$ mice, $\mathrm{A} 11$-positive $\mathrm{A} \beta$ oligomers positively correlated with TDP-43 $\left(\mathrm{r}^{2}=0.9330, \mathrm{p}=\right.$ 0.001; Figure 5G) and TDP-35 $\left(r^{2}=0.6749, p=0.045\right.$; Figure $5 \mathrm{H})$. Similarly, we found that A11 levels in 12month-old $3 \times \mathrm{Tg}-\mathrm{AD}$ mice positively correlate with TDP-43 $\left(\mathrm{r}^{2}=0.7259, \mathrm{p}=0.031\right.$; Figure $\left.5 \mathrm{I}\right)$. A strong trend was also observed when analyzing A11 and TDP35 levels in 12-month-old $3 \times \mathrm{Tg}$-AD mice $\left(\mathrm{r}^{2}=0.6277\right.$, $\mathrm{p}=0.06$; Figure 5J). Taken together, these data suggest that the increase in TDP- 43 in the $3 \times \mathrm{Tg}$ - AD mice may be due to the increase in soluble $A \beta$ oligomers.

The strong correlation between $A \beta$ oligomers and TDP-43 levels led us to hypothesize that the buildup of $\mathrm{A} \beta$ oligomers maybe the cause underlying the increase in TDP-43 levels in the $3 \times \mathrm{Tg}-\mathrm{AD}$ mice. To test this hypothesis we used a double transgenic mouse model (referred to as APP/tau mice) that we previously generated by replacing the mutant PS1 allele with its wild type counterpart in the $3 \times \mathrm{Tg}-\mathrm{AD}$ mice, thereby obtaining double transgenic mice expressing APP and tau [47]. Because of the M146V mutation in the PS1 gene, the $3 \times \mathrm{Tg}$-AD mice accumulate 10 times more $\mathrm{A} \beta_{42}$ than $\mathrm{A} \beta_{40}$ [38]. Thus, replacing the M146V mutation with its wild type counterpart significantly decreased $A \beta_{42}$ levels [47]. Here we used the APP/tau mice to determine the effects of preventing $A \beta$ oligomers accumulation on TDP-43 levels. At 6 month of age, the APP/tau mice show a significant reduction in intraneuronal $A \beta$ immunoreactivity compared to age- and gender-matched $3 \times \mathrm{Tg}$-AD mice (Figure 6A, B). Notably, the APP/tau mice did not show any M71/3 immunoreactivity (Figure $6 C)$. To determine the effect of preventing $A \beta$ accumulation on TDP-43, we measured the steady-state levels of TDP-43 and TDP-35 in the low salt fraction of proteins extracted from the brains of the APP/tau mice by Western blot (Figure 6D). We found that the levels of TDP-43 and TDP-35 were significantly lower in the brains of the APP/tau mice compared to $3 \times \mathrm{Tg}-\mathrm{AD}$ mice (Figure 6E-F). Notably, the levels of TDP-43 and TDP35 were not significantly different between APP/tau and NonTg mice. Taken together, the results presented here strongly argue of a causal relation between the build-up of $\mathrm{A} \beta$ oligomers and the increase in TDP- 43 levels.

\section{Discussion}

In addition to representing the major pathological protein that accumulates in CNS inclusions characterizing ALS and FTLD-U, TDP-43 positive inclusions have been found in $\sim 30 \%$ of AD cases [34,37,39]. Specifically, the accumulation of low molecular weight $\mathrm{C}$-terminal fragments has been reported in human $\mathrm{AD}$ patients [48]. Notably, these fragments may play a primary role in the disease pathogenesis as their expression in vitro is sufficient to cause TDP-43 mislocalization [31-33]. The clinical significance of TDP-43 accumulation in AD and its relation with the two neuropathological hallmarks of $\mathrm{AD}$ ( $\mathrm{A} \beta$ and tau) is not understood. In this study, we elucidate this relation using an animal model of AD. Our results indicate that in the brains of the $3 \times \mathrm{Tg}-\mathrm{AD}$ mice the levels of full length TDP-43 and its $\sim 35 \mathrm{kDa}$ $\mathrm{C}$-terminal fragment change as a function of age and $\mathrm{A} \beta$ oligomer levels. Notably, we found that TDP-43 and TDP-35 levels significantly correlated with $A \beta$ oligomers, thereby suggesting a possible relation between $A \beta$ and TDP-43. Toward this end, we found that TDP-43 and TDP-35 levels were higher in 6-month-old $3 \times \mathrm{Tg}$ AD mice compared to age-matched NonTg mice, but not at 12 months of age. Previously we showed that $A \beta$ oligomers levels in the $3 \times \mathrm{Tg}$ - AD mice peak at 6 months 


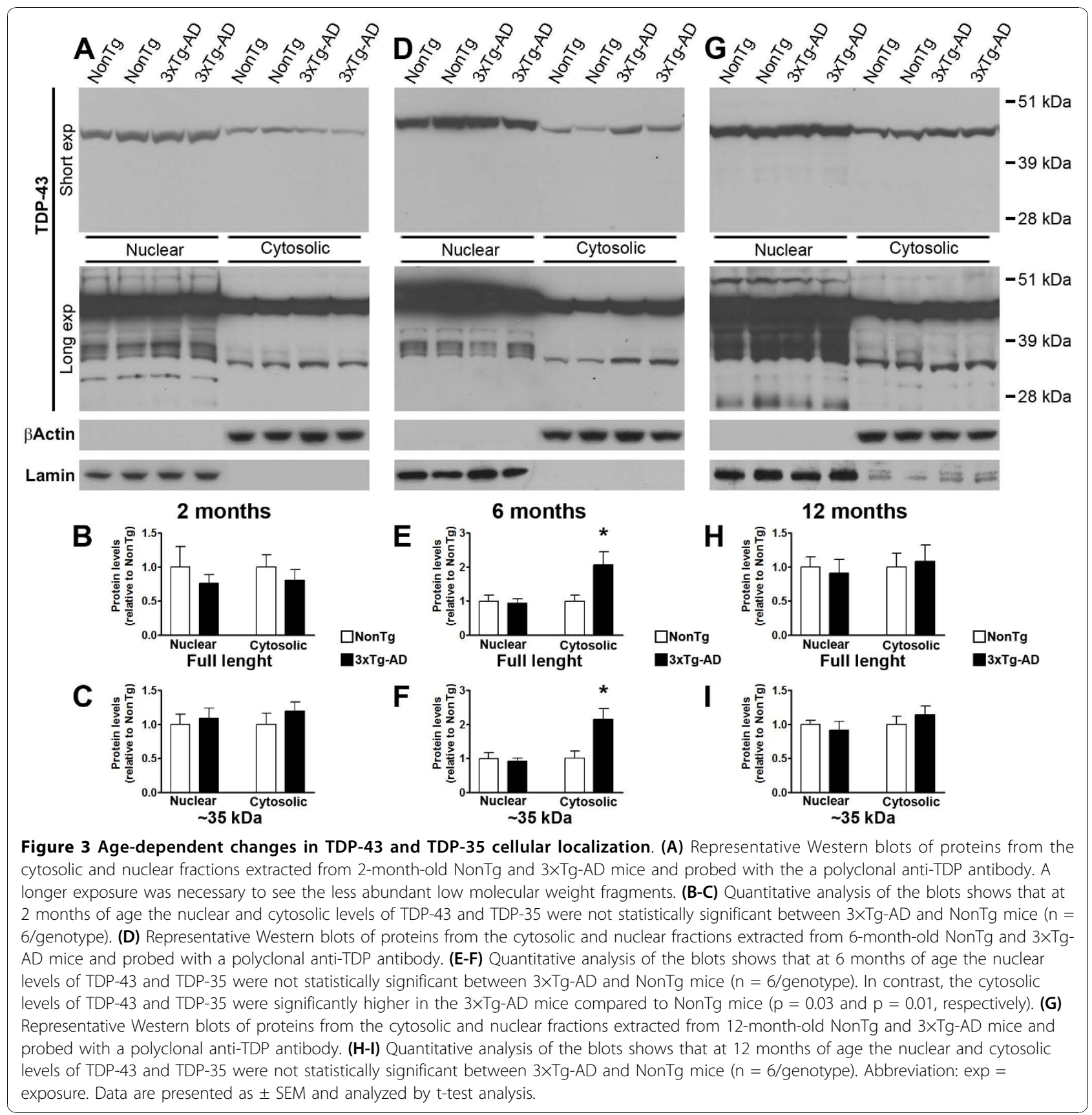

of age and are significantly lower at 12 months of age [44], which is consistent with the hypothesis that the increased TDP-43 levels in 6-month-old $3 \times \mathrm{Tg}$ - $\mathrm{AD}$ mice may be due to high levels of $A \beta$ oligomers. Indeed, we show that genetically preventing $A \beta_{42}$ accumulation in the $3 \times \mathrm{Tg}$-AD mice is sufficient to decrease TDP- 43 levels, further supporting an interaction between $A \beta$ and TDP-43.

It is widely accepted that $A \beta$ oligomers play a central role in AD pathogenesis [17-19]. Toward this end, it has been shown that low concentrations of $A \beta$ oligomers can kill neurons, impair LTP, and lead to cognitive decline [49-55]. A $\beta$ oligomers have been shown to interact with several signaling transduction pathways [56-61]. Although the mechanism underlying the $A \beta$-mediated accumulation of TDP- 43 in the $3 \times \mathrm{Tg}$ - AD mice remains to be elucidated, it is tempting to speculate that alterations in signaling transduction pathways due to the build-up of $A \beta$ oligomers may be responsible for TDP-43 accumulation and misprocessing. For example, caspase 3 and 7 can cleave TDP-43 and lead to the accumulation of TDP-43 fragments [62]. Notably, 


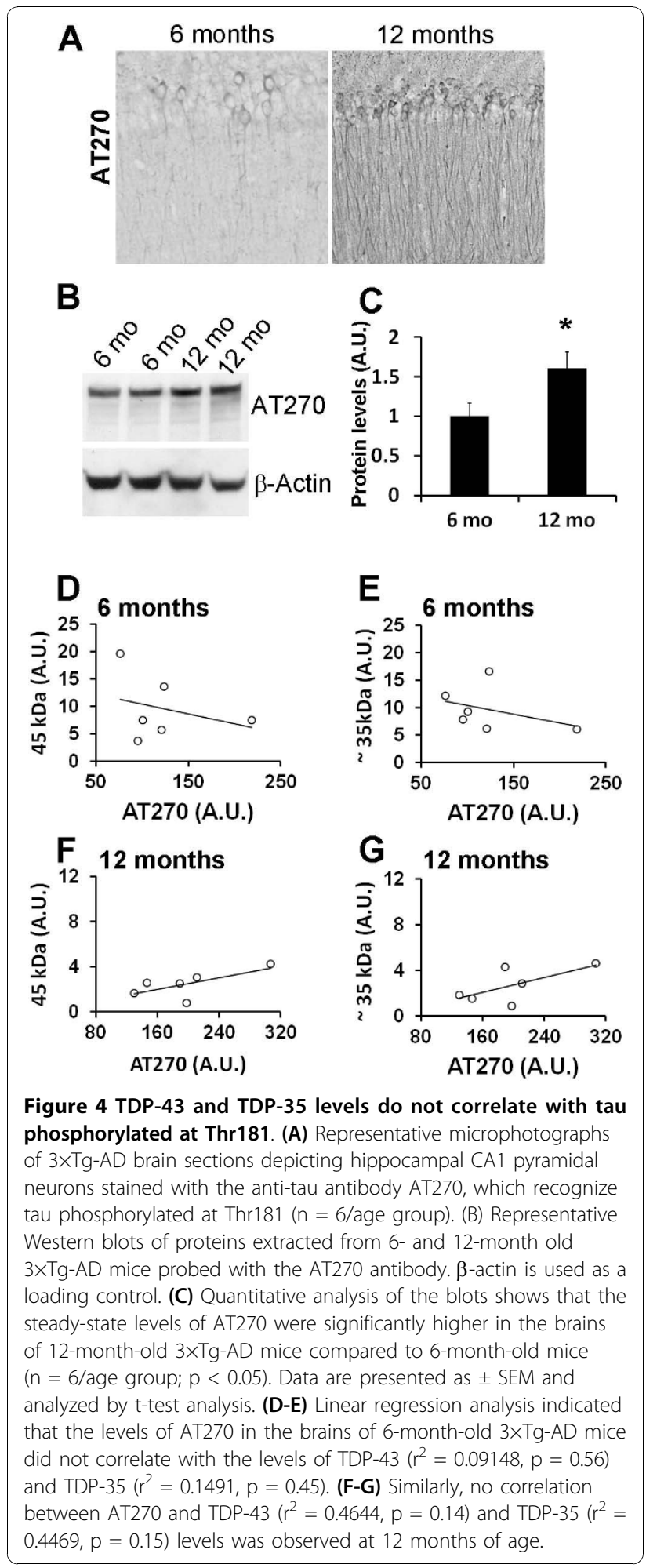

elevated caspase 7 mRNA levels have been reported in $\mathrm{AD}$ brains [63], and, more specifically, there is evidence that $A \beta$ oligomers can increase caspase activity [64-66]. This is consistent with data showing that TDP-43 can

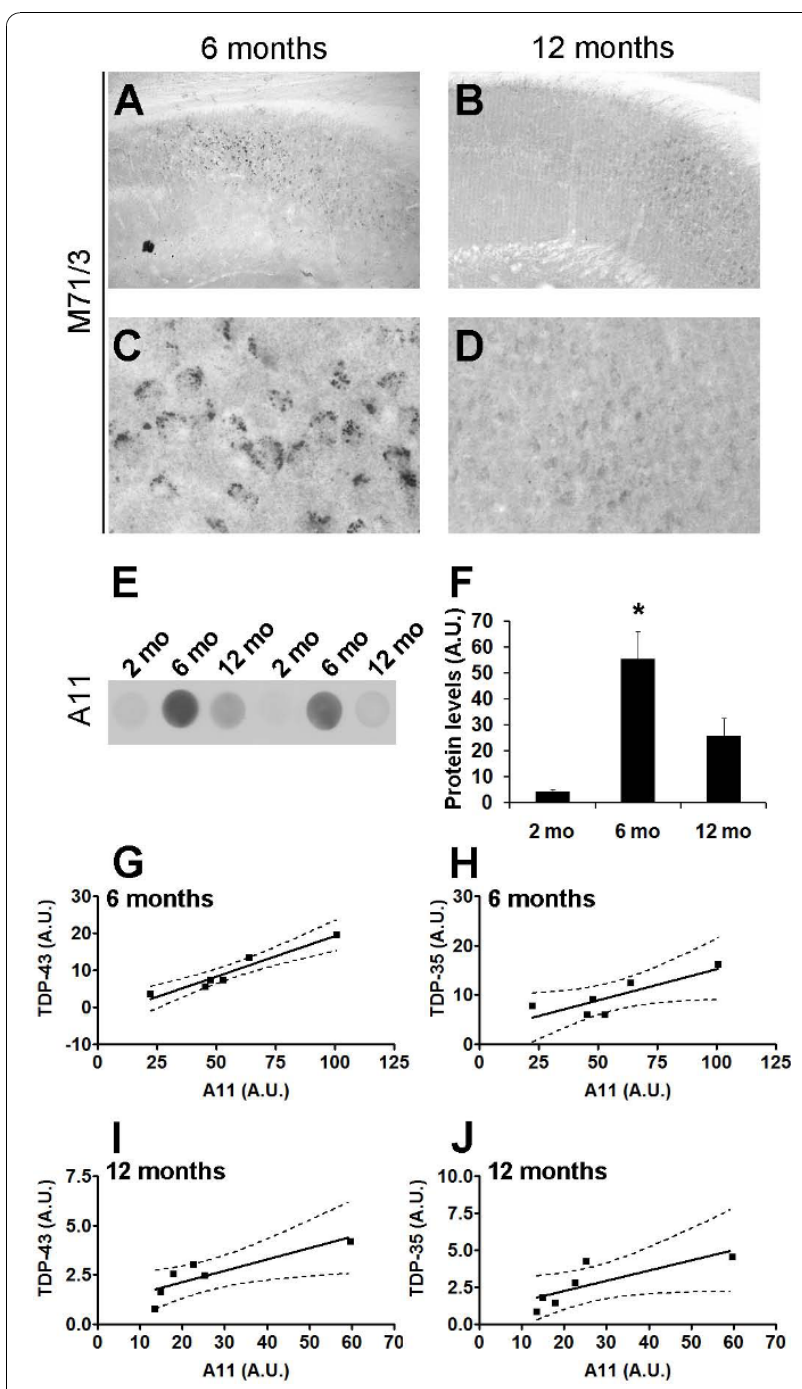

Figure 5 A $\beta$ oligomers correlate with TDP-43 and TDP-35. (A-D) Representative microphotographs showing $3 \times \mathrm{Tg}$-AD hippocampal sections stained with the antibody $M 71 / 3$, which is specific for $A \beta$ oligomers. Panels $C$ and $D$ show higher magnification views of panels $A$ and B, respectively ( $n=6 /$ age group). (E) Representative dot blots of protein extracted from 2-, 6-, and 12-month-old 3xTg-AD mice and probed with the antibody $A 11$, which is specific for $A \beta$ oligomers. (F) Quantitative analysis of the dot blots shows that at 6 months of age, A11 levels were significantly higher compared to 2month-old mice $(p<0.001)$ and 12-month-old mice $(p<0.05)$. (G-H) Linear regression analysis indicated that the levels of $A 11$ in the brains of 6-month-old 3XTg-AD mice significantly correlated with the levels of TDP-43 $\left(r^{2}=0.9330, p=0.001\right)$ and TDP-35 $\left(r^{2}=0.6749\right.$, $p=0.045)$. (I) Similarly, the levels of A11 in the brains of 12-monthold 3XTg-AD mice significantly correlated with TDP-43 $\left(r^{2}=0.7259\right.$, $p=0.031)$. (J) A strong trend was observed when analyzing A11 and TDP-35 levels in 12-month-old 3XTg-AD mice $\left(r^{2}=0.6277, p=0.06\right)$. The dotted lines in panels $\mathrm{G}-\mathrm{J}$ represent $95 \%$ confidence intervals.

be cleaved, in a caspase dependent manner, to generate TDP-43 C-terminal fragments [62]. Thus, it is tempting to speculate that an $A \beta$-increase in caspase activity may facilitate the formation of the $\sim 35 \mathrm{kDa}$ C-terminal 


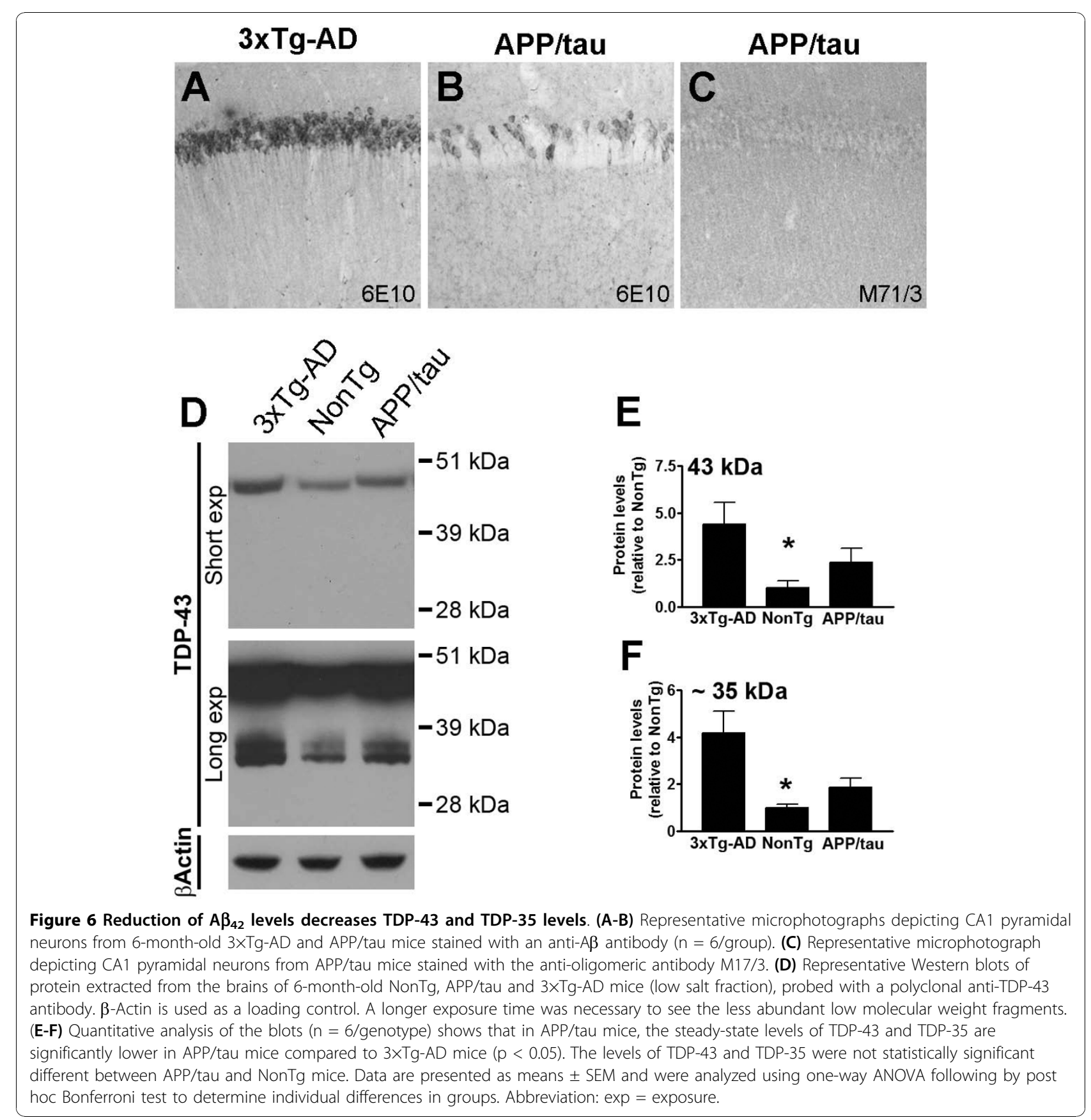

fragment of TDP-43. Additionally, our results show that cytosolic TDP-43 levels are higher in 6-month-old $3 \times$ Tg-AD mice compared to age- and gender-matched NonTg mice. Such an increase, however, was not due to a redistribution of TDP -43 from the nucleus into the cytoplasm as we found that nuclear TDP-43 levels were similar between $3 \times \mathrm{Tg}-\mathrm{AD}$ and NonTg mice. It is possible that a reduction in protein turnover may account for the higher levels of TDP-43 and TDP-35 in the $3 \times \mathrm{Tg}-$ AD mice. Notably, A $\beta$ oligomers have been shown to reduce the activity of the ubiquitin-proteasome-system and autophagy $[61,67]$, two major protein turnover systems that are involved in TDP-43 clearance as independently reported by several laboratories [31,68-70].

Contradicting reports have been published on the relation between TDP-43 and tau pathology. Specifically, in brains from AD patients, more often than not, tau immunoreactivity does not correlate with TDP-43 positive neurons [48], which is consistent with our data showing that TDP-43 and TDP-35 levels did not 
correlate with phosphorylated tau at Thr181. However, it has been reported that the Braak score for neurofibrillary tau pathology is higher in AD cases with TDP-43 immunoreactivity [48]. To complicate this apparent contradiction are the data showing that in dementia with Lewy bodies, a disease also characterized by tau accumulation, TDP-43 immunoreactivity is not related with Braak neurofibrillary tau pathology [48]. Although we found that in the $3 \times \mathrm{Tg}$-AD mice, TDP-43 levels did not correlate with tau phosphorylated at Thr181, further studies are needed to establish whether TDP-43 levels will change in relation to NFT, as suggested by some studies with human brains $[34,48]$, or with total tau levels. Specifically, the latter could not be addressed using the $3 \times \mathrm{Tg}$-AD mice, where the tau transgene does not change as a function of age and its steady-state level reflect the promoter activity. Thus any attempt of correlating total tau to TDP-43 would have been artificial. Furthermore, a report by Amador-Ortiz and colleagues shows that in some selective regions of AD brains, TDP-43 deposits correlate with phosphotau, whereas in other regions within the same brain, no correlation was found [34]. This apparent discrepancy could arise from the sample preparation; indeed, the data presented here from the $3 \times \mathrm{Tg}-\mathrm{AD}$ mice where obtained from whole brain homogenize and compare the levels of soluble tau and soluble TDP-43 and TDP-35. Finally, the relationship between other phosphotau epitopes and TDP-43 remains to be determined.

\section{Conclusions}

The data presented here provide compelling evidence that in the brain of the $3 \times \mathrm{Tg}-\mathrm{AD}$ mice, the accumulation of soluble $A \beta$ oligomers may be responsible for the increase in the steady-state levels of TDP-43 and TDP35 . It should be noted, however, that the biochemical profile of TDP -43 detected in the $3 \times \mathrm{Tg}$-AD mice was different from that believed pathogenic in FTLD-U [29], suggesting that in these mice changes in TDP-43 levels do not play a role in the $\mathrm{AD}$-like phenotype developed by these mice. Further studies will be needed to elucidate whether TDP-43 plays a clinical role in AD pathogenesis.

\section{Materials and methods Mice}

The generation of the $3 \times \mathrm{Tg}-\mathrm{AD}$ and $\mathrm{APP} /$ tau mice was previously described $[38,47]$. Briefly, the $3 \times \mathrm{Tg}-\mathrm{AD}$ mice were generated by co-injecting two different transgenes encoding human APPswe and human tau P301L, both under the control of the Thy1.2 promoter, into singlecell embryos harvested from homozygous mutant PS1M146V knock-in mice (PS1-KI). The APP/tau mice were generated crossing homozygous $3 \times \mathrm{Tg}$-AD mice with NonTg mice to replace the mutant PS1 allele with its wild type counterpart.

\section{Immunohistochemistry}

Mice were sacrificed by $\mathrm{CO}_{2}$ asphyxiation and their brains rapidly removed and dropped fixed for 48 hours in $4 \%$ paraformaldehyde. Free-floating sections $(50 \mu \mathrm{m}$ thick) were obtained using a vibratome slicing system (Leica VT1200S, Germany) and stored in $0.02 \%$ sodium azide in PBS. Following two washes with TBS, endogenous peroxidase activity was quenched for 30 minutes in $3 \% \mathrm{H}_{2} \mathrm{O}_{2}$. For epitope exposure sections were next incubated in $90 \%$ formic acid for 7 minutes, followed by tree additional washes in TBS (100 mM Tris pH 7.5; 150 $\mathrm{mM} \mathrm{NaCl}$ ). The proper primary antibody was applied overnight at $4^{\circ} \mathrm{C}$. Sections were washed 3 times in TBS and then incubated with the suitable secondary antibody for 1 hour at room temperature. Sections were then developed with diaminobenzidine (DAB) substrate using the avidin-biotin horseradish peroxidase system (Vector Labs, Burlingame, CA).

\section{Protein extraction}

Following $\mathrm{CO}_{2}$ asphyxiation, brains were extracted and frozen in dry ice. To obtain the low and high salt fractions, brains were homogenized with a power homogenizer in $1 \mathrm{ml}$ of low salt buffer (10 mM Tris pH7.5, $5 \mathrm{mM}$ EDTA, $1 \mathrm{mM}$ DTT, 10\% Sucrose) in the presence of protease inhibitors. Samples were then centrifuged at $14,400 \mathrm{rpm}$ for 30 minutes at $4^{\circ} \mathrm{C}$. The supernatant was stored at $-80^{\circ} \mathrm{C}$ as low salt fraction. To obtain the cytosolic and nuclear fractions, brains were washed in PBS and then homogenized with a dounce homogenizer with $2 \mathrm{ml}$ of solution A (10 mM Hepes pH7.9, $10 \mathrm{mM} \mathrm{KCL}$, $0.1 \mathrm{mM}$ EDTA, $0.1 \mathrm{mM}$ EGTA, $1 \mathrm{mM}$ DTT) in the presence of protease inhibitors. After 5 initial strokes, $0.5 \%$ of NP40 was added, and the brain was further homogenized with 5 additional strokes. Subsequently, the solution was kept in ice for 10 minutes and centrifuged 1 minute at 11,000 rpm. The supernatant was removed and stored at $-80^{\circ} \mathrm{C}$ as cytosolic fraction. The pellet was re-suspended in $250 \mu \mathrm{l}$ of Solution B (20 mM Hepes pH7.9, $400 \mathrm{mM} \mathrm{Nacl} 1 \mathrm{mM}$ EDTA, $1 \mathrm{mM}$ EGTA, 1 $\mathrm{mM}$ DTT) in the presence of protease inhibitors and placed in ice for 15 minutes. Finally, the tubes were centrifuged 5 minutes at $11,000 \mathrm{rpm}$ and the supernatant was stored at $-80^{\circ} \mathrm{C}$ as nuclear fraction.

\section{Western blot and dot blot}

Proteins were resolved using precast SDS/PAGE gels (Invitrogen, Carlsbad, CA) under reducing conditions and transferred to a nitrocellulose membrane. The membrane was incubated in a $5 \%$ solution of non-fat dry milk in T-TBS $(0.02 \%$ Tween $20,100 \mathrm{mM}$ Tris $\mathrm{pH}$ 
$7.5 ; 150 \mathrm{nM} \mathrm{NaCl}$ ) for 1 hour at $20^{\circ} \mathrm{C}$. The membrane was then incubated in the proper primary antibody at $4^{\circ} \mathrm{C}$ overnight. The blots were washed in T-TBS for 20 minutes and incubated at $20^{\circ} \mathrm{C}$ with the appropriate secondary antibody for 1 hour. After a final 20-minute wash in T-TBS, blots were developed for 5 minutes with Super Signal (Pierce, Rockford, IL), washed and exposed. For dot-blots, proteins were applied in a nitrocellulose membrane and air dried. Membranes were resolved as described above.

\section{Antibodies}

The following antibodies were used in this study: AT270 (Pierce, Rockford, IL) anti- $\beta$-actin (Sigma, St. Louis, $\mathrm{MO})$, rabbit anti human TARDBP polyclonal antibody (ProteinTech Group, Chicago, IL), A11 (a gift from Dr. Charles Glabe, University of California, Irvine), M71/3 (a gift from Dr. William Klein, Northwestern University, Evanston, IL).

\section{Statistical evaluation}

The data were subsequently analyzed by ANOVA or ttest comparison as detailed in the figure legends, using Graphpad Prism software (Graphpad Prism Inc., San Diego, CA).

\section{Acknowledgements}

This work was supported by K99/R00 AG29729-4 (Oddo, PI). A.M. was an exchange student from the University of Catania, Italy, partially supported by a traveling award from the University of Catania.

\section{Authors' contributions}

AC designed the study, executed most of the experiments and analyzed the data. AM executed some of the Western blots. SO designed the study, analyzed the data and wrote the paper. All authors read and approved the final manuscript.

\section{Competing interests}

The authors declare that they have no competing interests.

Received: 5 October 2010 Accepted: 11 November 2010 Published: 11 November 2010

\section{References}

1. Ferri $\mathrm{CP}$, Prince $\mathrm{M}$, Brayne C, Brodaty $\mathrm{H}$, Fratiglioni L, Ganguli M, Hall K Hasegawa $K$, Hendrie $H$, Huang $Y$, et al: Global prevalence of dementia: a Delphi consensus study. Lancet 2005, 366:2112-2117.

2. Artero S, Tierney MC, Touchon J, Ritchie K: Prediction of transition from cognitive impairment to senile dementia: a prospective, longitudinal study. Acta psychiatrica Scandinavica 2003, 107:390-393.

3. Lambon Ralph MA, Patterson K, Graham N, Dawson K, Hodges JR Homogeneity and heterogeneity in mild cognitive impairment and Alzheimer's disease: a cross-sectional and longitudinal study of 55 cases. Brain 2003, 126:2350-2362.

4. Welsh KA, Butters N, Hughes JP, Mohs RC, Heyman A: Detection and staging of dementia in Alzheimer's disease. Use of the neuropsychological measures developed for the Consortium to Establish a Registry for Alzheimer's Disease. Archives of neurology 1992, 49:448-452.

5. Selkoe DJ: Alzheimer's disease: genes, proteins, and therapy. Physiological reviews 2001, 81:741-766.

6. Oddo S: The ubiquitin-proteasome system in Alzheimer's disease. J Cell Mol Med 2008, 12:363-373.
7. LaFerla FM, Green KN, Oddo S: Intracellular amyloid-beta in Alzheimer's disease. Nature reviews 2007, 8:499-509.

8. Pratico D: Alzheimer's disease and oxygen radicals: new insights. Biochemical pharmacology 2002, 63:563-567.

9. Funderburk SF, Marcellino BK, Yue Z: Cell "self-eating" (autophagy) mechanism in Alzheimer's disease. Mt Sinai J Med 2010, 77:59-68.

10. Masters $\mathrm{CL}$, Simms G, Weinman NA, Multhaup G, McDonald BL, Beyreuther K: Amyloid plaque core protein in Alzheimer disease and Down syndrome. Proceedings of the National Academy of Sciences of the United States of America 1985, 82:4245-4249.

11. Glenner GG, Wong CW: Alzheimer's disease: initial report of the purification and characterization of a novel cerebrovascular amyloid protein. Biochemical and biophysical research communications 1984, 120:885-890.

12. Hardy J, Selkoe DJ: The amyloid hypothesis of Alzheimer's disease: progress and problems on the road to therapeutics. Science (New York, NY) 2002, 297:353-356.

13. Scheuner D, Eckman C, Jensen M, Song X, Citron M, Suzuki N, Bird TD, Hardy J, Hutton M, Kukull W, et al: Secreted amyloid beta-protein similar to that in the senile plaques of Alzheimer's disease is increased in vivo by the presenilin 1 and 2 and APP mutations linked to familial Alzheimer's disease. Nature medicine 1996, 2:864-870.

14. Sherrington R, Rogaev El, Liang $Y$, Rogaeva EA, Levesque $G$, Ikeda M, Chi H, Lin C, Li G, Holman K, et al: Cloning of a gene bearing missense mutations in early-onset familial Alzheimer's disease. Nature 1995 375:754-760.

15. Goate A, Chartier-Harlin MC, Mullan M, Brown J, Crawford F, Fidani L, Giuffra L, Haynes A, Irving N, James L, et al: Segregation of a missense mutation in the amyloid precursor protein gene with familial Alzheimer's disease. Nature 1991, 349:704-706.

16. Chartier-Harlin MC, Crawford F, Houlden H, Warren A, Hughes D, Fidani L, Goate A, Rossor M, Roques P, Hardy J, et al: Early-onset Alzheimer's disease caused by mutations at codon 717 of the beta-amyloid precursor protein gene. Nature 1991, 353:844-846

17. Glabe CC: Amyloid accumulation and pathogensis of Alzheimer's disease: significance of monomeric, oligomeric and fibrillar Abeta. Sub-cellular biochemistry 2005, 38:167-177.

18. Klein WL: Abeta toxicity in Alzheimer's disease: globular oligomers (ADDLs) as new vaccine and drug targets. Neurochemistry international 2002, 41:345-352.

19. Selkoe DJ: Soluble oligomers of the amyloid beta-protein impair synaptic plasticity and behavior. Behavioural brain research 2008, 192:106-113.

20. Kosik KS, Joachim CL, Selkoe DJ: Microtubule-associated protein tau (tau) is a major antigenic component of paired helical filaments in Alzheimer disease. Proceedings of the National Academy of Sciences of the United States of America 1986, 83:4044-4048.

21. Ihara $Y$, Nukina N, Miura R, Ogawara M: Phosphorylated tau protein is integrated into paired helical filaments in Alzheimer's disease. Journal of biochemistry 1986, 99:1807-1810.

22. Grundke-labal I, lqbal K, Tung YC, Quinlan M, Wisniewski HM, Binder LI: Abnormal phosphorylation of the microtubule-associated protein tau (tau) in Alzheimer cytoskeletal pathology. Proceedings of the National Academy of Sciences of the United States of America 1986, 83:4913-4917.

23. Goedert M, Wischik CM, Crowther RA, Walker JE, Klug A: Cloning and sequencing of the CDNA encoding a core protein of the paired helical filament of Alzheimer disease: identification as the microtubuleassociated protein tau. Proceedings of the National Academy of Sciences of the United States of America 1988, 85:4051-4055.

24. Oddo S, Vasilevko V, Caccamo A, Kitazawa M, Cribbs DH, LaFerla FM: Reduction of soluble Abeta and tau, but not soluble Abeta alone, ameliorates cognitive decline in transgenic mice with plaques and tangles. J Biol Chem 2006, 281:39413-39423.

25. Mandelkow EM, Stamer K, Vogel R, Thies E, Mandelkow E: Clogging of axons by tau, inhibition of axonal traffic and starvation of synapses. Neurobiol Aging 2003, 24:1079-1085.

26. Santacruz K, Lewis J, Spires T, Paulson J, Kotilinek L, Ingelsson M, Guimaraes A, DeTure M, Ramsden M, McGowan E, et al: Tau suppression in a neurodegenerative mouse model improves memory function. Science (New York, NY) 2005, 309:476-481

27. Wittmann CW, Wszolek MF, Shulman JM, Salvaterra PM, Lewis J, Hutton M, Feany MB: Tauopathy in Drosophila: neurodegeneration without neurofibrillary tangles. Science (New York, NY) 2001, 293:711-714. 
28. Buratti E, Baralle FE: Multiple roles of TDP-43 in gene expression, splicing regulation, and human disease. Front Biosci 2008, 13:867-878.

29. Neumann M, Sampathu DM, Kwong LK, Truax AC, Micsenyi MC, Chou TT, Bruce J, Schuck T, Grossman M, Clark CM, et al: Ubiquitinated TDP-43 in frontotemporal lobar degeneration and amyotrophic lateral sclerosis. Science (New York, NY) 2006, 314:130-133.

30. Igaz LM, Kwong LK, Xu Y, Truax AC, Uryu K, Neumann M, Clark CM, Elman LB, Miller BL, Grossman M, et al: Enrichment of C-terminal fragments in TAR DNA-binding protein-43 cytoplasmic inclusions in brain but not in spinal cord of frontotemporal lobar degeneration and amyotrophic lateral sclerosis. The American journal of pathology 2008, 173:182-194.

31. Caccamo A, Majumder S, Deng JJ, Bai Y, Thornton FB, Oddo S: Rapamycin rescues TDP-43 mislocalization and the associated low molecular weight neurofilament instability. J Biol Chem 2009, 284:27416-24.

32. Igaz LM, Kwong LK, Chen-Plotkin A, Winton MJ, Unger TL, Xu Y, Neumann M, Trojanowski JQ, Lee VM: Expression of TDP-43 C-terminal Fragments in Vitro Recapitulates Pathological Features of TDP-43 Proteinopathies. J Biol Chem 2009, 284:8516-8524.

33. Nonaka T, Kametani F, Arai T, Akiyama H, Hasegawa M: Truncation and pathogenic mutations facilitate the formation of intracellular aggregates of TDP-43. Human molecular genetics 2009, 18:3353-3364.

34. Amador-Ortiz C, Lin WL, Ahmed Z, Personett D, Davies P, Duara R, GraffRadford NR, Hutton ML, Dickson DW: TDP-43 immunoreactivity in hippocampal sclerosis and Alzheimer's disease. Annals of neurology 2007, 61:435-445.

35. Bigio EH: TAR DNA-binding protein-43 in amyotrophic lateral sclerosis, frontotemporal lobar degeneration, and Alzheimer disease. Acta neuropathologica 2008, 116:135-140.

36. Higashi S, Iseki E, Yamamoto R, Minegishi M, Hino H, Fujisawa K, Togo T, Katsuse O, Uchikado H, Furukawa Y, et al: Concurrence of TDP-43, tau and alpha-synuclein pathology in brains of Alzheimer's disease and dementia with Lewy bodies. Brain research 2007, 1184:284-294.

37. Uryu K, Nakashima-Yasuda H, Forman MS, Kwong LK, Clark CM, Grossman M, Miller BL, Kretzschmar HA, Lee VM, Trojanowski JQ, Neumann M: Concomitant TAR-DNA-binding protein 43 pathology is present in Alzheimer disease and corticobasal degeneration but not in other tauopathies. Journal of neuropathology and experimental neurology 2008, 67:555-564.

38. Oddo S, Caccamo A, Shepherd JD, Murphy MP, Golde TE, Kayed R, Metherate R, Mattson MP, Akbari Y, LaFerla FM: Triple-transgenic model of Alzheimer's disease with plaques and tangles: intracellular Abeta and synaptic dysfunction. Neuron 2003, 39:409-421.

39. Hu WT, Josephs KA, Knopman DS, Boeve BF, Dickson DW, Petersen RC, Parisi JE: Temporal lobar predominance of TDP-43 neuronal cytoplasmic inclusions in Alzheimer disease. Acta neuropathologica 2008, 116:215-220.

40. Kadokura A, Yamazaki T, Lemere CA, Takatama M, Okamoto K: Regional distribution of TDP-43 inclusions in Alzheimer disease (AD) brains: Their relation to AD common pathology. Neuropathology 2009, 5:566-73.

41. Oddo S, Caccamo A, Kitazawa M, Tseng BP, LaFerla FM: Amyloid deposition precedes tangle formation in a triple transgenic model of Alzheimer's disease. Neurobiol Aging 2003, 24:1063-1070

42. Oddo S, Caccamo A, Cheng D, Jouleh B, Torp R, LaFerla FM: Genetically augmenting tau levels does not modulate the onset or progression of Abeta pathology in transgenic mice. J Neurochem 2007, 102:1053-1063.

43. Billings $L M$, Green KN, McGaugh JL, LaFerla FM: Learning decreases A beta*56 and tau pathology and ameliorates behavioral decline in 3×TgAD mice. J Neurosci 2007, 27:751-761.

44. Oddo S, Caccamo A, Tran L, Lambert MP, Glabe CG, Klein WL, LaFerla FM: Temporal profile of amyloid-beta (Abeta) oligomerization in an in vivo model of Alzheimer disease. A link between Abeta and tau pathology. J Biol Chem 2006, 281:1599-1604

45. Gong Y, Chang L, Viola KL, Lacor PN, Lambert MP, Finch CE, Krafft GA Klein WL: Alzheimer's disease-affected brain: presence of oligomeric $A$ beta ligands (ADDLs) suggests a molecular basis for reversible memory loss. Proc Natl Acad Sci USA 2003, 100:10417-10422.

46. Kayed R, Head E, Thompson JL, McIntire TM, Milton SC, Cotman CW, Glabe CG: Common structure of soluble amyloid oligomers implies common mechanism of pathogenesis. Science (New York, NY) 2003, 300:486-489.
47. Oddo S, Caccamo A, Tseng B, Cheng D, Vasilevko V, Cribbs DH, LaFerla FM: Blocking Abeta42 accumulation delays the onset and progression of tau pathology via the $\mathrm{C}$ terminus of heat shock protein70-interacting protein: a mechanistic link between Abeta and tau pathology. J Neurosci 2008, 28:12163-12175

48. Arai T, Mackenzie IR, Hasegawa M, Nonoka T, Niizato K, Tsuchiya K, Iritani S, Onaya M, Akiyama H: Phosphorylated TDP-43 in Alzheimer's disease and dementia with Lewy bodies. Acta neuropathologica 2009, 117:125-136.

49. Cleary JP, Walsh DM, Hofmeister JJ, Shankar GM, Kuskowski MA, Selkoe DJ, Ashe KH: Natural oligomers of the amyloid-beta protein specifically disrupt cognitive function. Nat Neurosci 2005, 8:79-84.

50. Demuro A, Mina E, Kayed R, Milton SC, Parker I, Glabe CG: Calcium dysregulation and membrane disruption as a ubiquitous neurotoxic mechanism of soluble amyloid oligomers. J Biol Chem 2005, 280:17294-17300.

51. Kayed R, Sokolov Y, Edmonds B, McIntire TM, Milton SC, Hall JE, Glabe CG: Permeabilization of lipid bilayers is a common conformation-dependent activity of soluble amyloid oligomers in protein misfolding diseases. J Biol Chem 2004, 279:46363-46366.

52. Klyubin I, Walsh DM, Lemere CA, Cullen WK, Shankar GM, Betts V, Spooner ET, Jiang L, Anwyl R, Selkoe DJ, Rowan MJ: Amyloid beta protein immunotherapy neutralizes Abeta oligomers that disrupt synaptic plasticity in vivo. Nat Med 2005, 11:556-561.

53. Lambert MP, Barlow AK, Chromy BA, Edwards C, Freed R, Liosatos M, Morgan TE, Rozovsky I, Trommer B, Viola KL, et al: Diffusible, nonfibrillar ligands derived from Abeta1-42 are potent central nervous system neurotoxins. Proc Natl Acad Sci USA 1998, 95:6448-6453.

54. Walsh DM, Klyubin I, Fadeeva JV, Cullen WK, Anwyl R, Wolfe MS, Rowan MJ, Selkoe DJ: Naturally secreted oligomers of amyloid beta protein potently inhibit hippocampal long-term potentiation in vivo. Nature 2002, 416:535-539.

55. Wang HW, Pasternak JF, Kuo H, Ristic H, Lambert MP, Chromy B, Viola KL, Klein WL, Stine WB, Krafft GA, Trommer BL: Soluble oligomers of beta amyloid (1-42) inhibit long-term potentiation but not long-term depression in rat dentate gyrus. Brain Res 2002, 924:133-140.

56. Dickey CA, De Mesquita DD, Morgan D, Pennypacker KR: Induction of memory-associated immediate early genes by nerve growth factor in rat primary cortical neurons and differentiated mouse Neuro2A cells. Neuroscience letters 2004, 366:10-14

57. Gong B, Cao Z, Zheng P, Vitolo OV, Liu S, Staniszewski A, Moolman D, Zhang H, Shelanski M, Arancio O: Ubiquitin hydrolase Uch-L1 rescues beta-amyloid-induced decreases in synaptic function and contextual memory. Cell 2006, 126:775-788.

58. Anderson AJ, Cummings BJ, Cotman CW: Increased immunoreactivity for Jun- and Fos-related proteins in Alzheimer's disease: association with pathology. Experimental neurology 1994, 125:286-295.

59. MacGibbon GA, Lawlor PA, Walton M, Sirimanne E, Faull RL, Synek B, Mee E, Connor B, Dragunow M: Expression of Fos, Jun, and Krox family proteins in Alzheimer's disease. Experimental neurology 1997, 147:316-332.

60. von der Kammer H, Demiralay C, Andresen B, Albrecht C, Mayhaus M, Nitsch RM: Regulation of gene expression by muscarinic acetylcholine receptors. Biochemical Society symposium 2001, 131-140.

61. Caccamo A, Majumder S, Richardson A, Strong R, Oddo S: Molecular interplay between mammalian target of rapamycin (mTOR), amyloidbeta, and Tau: effects on cognitive impairments. J Biol Chem 2010, 285:13107-13120.

62. Zhang YJ, Xu YF, Dickey CA, Buratti E, Baralle F, Bailey R, Pickering-Brown S, Dickson D, Petrucelli L: Progranulin mediates caspase-dependent cleavage of TAR DNA binding protein-43. J Neurosci 2007, 27:10530-10534.

63. Matsui T, Ramasamy K, Ingelsson M, Fukumoto H, Conrad C, Frosch MP, Irizarry MC, Yuan J, Hyman BT: Coordinated expression of caspase 8, 3 and 7 mRNA in temporal cortex of Alzheimer disease: relationship to formic acid extractable abeta42 levels. Journal of neuropathology and experimental neurology 2006, 65:508-515.

64. Chong YH, Shin YJ, Lee EO, Kayed R, Glabe CG, Tenner AJ: ERK1/2 activation mediates Abeta oligomer-induced neurotoxicity via caspase-3 activation and tau cleavage in rat organotypic hippocampal slice cultures. J Biol Chem 2006, 281:20315-20325.

65. Picone P, Carrotta R, Montana G, Nobile MR, San Biagio PL, Di Carlo M: Abeta oligomers and fibrillar aggregates induce different apoptotic 
pathways in LAN5 neuroblastoma cell cultures. Biophysical journal 2009, 96:4200-4211.

66. Resende R, Ferreiro E, Pereira C, Resende de Oliveira C: Neurotoxic effect of oligomeric and fibrillar species of amyloid-beta peptide 1-42: involvement of endoplasmic reticulum calcium release in oligomerinduced cell death. Neuroscience 2008, 155:725-737.

67. Tseng BP, Green KN, Chan JL, Blurton-Jones M, LaFerla FM: Abeta inhibits the proteasome and enhances amyloid and tau accumulation. Neurobiol Aging 2008, 29:1607-1618.

68. Zhang YJ, Gendron TF, Xu YF, Ko LW, Yen SH, Petrucelli L: Phosphorylation regulates proteasomal-mediated degradation and solubility of TAR DNA binding protein-43 C-terminal fragments. Mol Neurodegener 2010, 5:33.

69. Wang X, Fan H, Ying Z, Li B, Wang H, Wang G: Degradation of TDP-43 and its pathogenic form by autophagy and the ubiquitin-proteasome system. Neuroscience letters 2010, 469:112-116.

70. Urushitani M, Sato T, Bamba H, Hisa Y, Tooyama I: Synergistic effect between proteasome and autophagosome in the clearance of polyubiquitinated TDP-43. J Neurosci Res 2010, 88:784-797.

doi:10.1186/1750-1326-5-51

Cite this article as: Caccamo et al:: Age-dependent changes in TDP-43

levels in a mouse model of Alzheimer disease are linked to $A \beta$

oligomers accumulation. Molecular Neurodegeneration 2010 5:51.

\section{Submit your next manuscript to BioMed Central} and take full advantage of:

- Convenient online submission

- Thorough peer review

- No space constraints or color figure charges

- Immediate publication on acceptance

- Inclusion in PubMed, CAS, Scopus and Google Scholar

- Research which is freely available for redistribution

Submit your manuscript at www.biomedcentral.com/submit
Biomed Central 